\title{
Nitrification contributes to winter oxygen depletion in seasonally frozen forested lakes
}

\author{
S. M. Powers • H. M. Baulch • S. E. Hampton · S. G. Labou • N. R. Lottig • \\ E. H. Stanley
}

Received: 26 May 2017/Accepted: 14 September 2017/Published online: 17 October 2017

(C) The Author(s) 2017. This article is an open access publication

\begin{abstract}
In lakes that experience seasonal ice cover, understanding of nitrogen-oxygen coupling and nitrification has been dominated by observations during open water, ice-free conditions. To address knowledge gaps about nitrogen-oxygen linkages under ice, we examined long-term winter data $(30+$ years, $2-3$ sample events per winter) in 7 temperate lakes of forested northern Wisconsin, USA. Across lakes and depths, there were strong negative relationships between dissolved oxygen (DO) and the number of days since ice-on, reflecting consistent DO consumption rates under ice. In two bog lakes that routinely experience prolonged winter DO concentrations below $1.0 \mathrm{mg} \mathrm{L}^{-1}$, nitrate accumulated near the ice surface mainly in late winter, suggesting nitrification may depend on biogenic oxygen from photosynthesis. In contrast, within five oligotrophic-
\end{abstract}

Responsible Editor: Marc G. Kramer.

Electronic supplementary material The online version of this article (doi:10.1007/s10533-017-0382-1) contains supplementary material, which is available to authorized users.

S. M. Powers $(\bowtie) \cdot$ S. E. Hampton · S. G. Labou School of the Environment and Center for Environmental Research, Education and Outreach, Washington State University, Pullman, WA 99164, USA

e-mail: steve.powers@wsu.edu

H. M. Baulch

School of Environment and Sustainability, and Global Institute for Water Security, University of Saskatchewan, 11 Innovation Boulevard, Saskatoon, SK S7NH5, Canada mesotrophic lakes, nitrate accumulated more consistently over winter and often throughout the water column, especially at intermediate depths. Exogenous inputs of nitrate to these lakes were minimal compared to rates of nitrate accumulation. To produce the nitrate via in-lake nitrification, substantial oxygen consumption by ammonium oxidizing microbes would be required. Among lakes and depths that had significant DO depletion over winter, the stoichiometric nitrifier oxygen demand ranged from 1 to $25 \%$ of the DO depletion rate. These estimates of nitrifier-driven DO decline are likely conservative because we did not account for nitrate consumed by algal uptake or denitrification. Our results provide an example of nitrification at temperatures $<5$ degrees $\mathrm{C}$ having a substantial influence on ecosystem-level nitrogen and oxygen availability in seasonally-frozen, northern forested lakes. Consequently, models of under-ice dissolved oxygen dynamics may be advanced through consideration of nitrification, and more broadly, coupled nitrogen and oxygen cycling.

\footnotetext{
N. R. Lottig

Trout Lake Station, Center for Limnology, University of Wisconsin-Madison, 3110 Trout Lake Station Dr., Boulder Junction, Wisconsin 54512, USA

E. H. Stanley

Center for Limnology, University of Wisconsin-Madison, 680 N. Park St., Madison, WI 53706, USA
} 
Keywords Nitrate Ice $\cdot$ North temperate lakes · Oxygen $\cdot$ Winter $\cdot$ Nitrification

\section{Introduction}

Most naturally formed freshwater lakes are located above $45^{\circ}$ North (Verpoorter et al. 2014) and typically freeze during winter. Following from work by Striegl et al. (2001), a surge of recent research has confirmed that biogenic gases often accumulate over winter in seasonally frozen lakes (Ducharme-Riel et al. 2015; Denfeld et al. 2016) along with oxidized solutes including nitrate, sulfate, and carbonate/bicarbonate from methane oxidation (Gammons et al. 2014; Hanson et al. 2006; Powers et al. 2017). These findings point to active benthic and planktonic communities (Bertilsson et al. 2013; Hampton et al. 2017) that affect whole-lake chemistry through sustained aerobic and anaerobic biological processes under ice-which may not be surprising given similar observations from permanently frozen lakes (Morgan-Kiss et al. 2016; Powers and Hampton 2016).

Though not often addressed in oxygen-based studies in aquatic ecosystems, nitrification directly accounts for a portion of oxygen consumption (Hall and Jeffries 1984; Clevinger et al. 2014). Microbial oxygen consumption may be particularly influential when ice and snow cover a lake's surface, because airwater gas exchange is essentially cut off while oxygen production from aquatic photoautotrophs can be low due to darkness (Kirillin et al. 2012; McKnight et al. 2000). In extreme cases of oxygen depletion, "winterkill" of fish can occur (Magnuson et al. 1985). However, surprisingly little is known about the rates of nitrification under ice in seasonally frozen lakes, and how this nitrogen $(\mathrm{N})$ transformation is related to a lake's winter oxygen budget (but see Knowles and Lean 1987).

Understanding about nitrification beneath lake ice and its resulting effects on oxygen dynamics could guide future applications and interpretations of oxygen-based ecosystem metabolism models. One consideration is that ecosystem respiration rates derived from fitted nighttime oxygen data reflect integrated oxygen consumption rates, including autotrophic processes such as nitrification, and thus may overestimate aerobic respiration. A second consideration is that photoinhibition of nitrification during the day (French et al. 2012) might introduce a diel cycle, especially when clear ice forms (Katz et al. 2015), potentially influencing the validity of the assumption that daytime and nighttime ecosystem respiration rates are equal (Winslow et al. 2016). These examples reflect upper limits to the amount of biological information that can be extracted from oxygen-based models alone, especially in systems where dissolved oxygen and inorganic carbon are not perfectly coupled, as would be expected when processes such as nitrification contribute substantially to the oxygen dynamics.

Recently Powers et al. (2017) found that nitrate accumulated overwinter, using $>30$ years of underice measurements in five northern oligotrophic and mesotrophic lakes. The results suggested strong seasonal forcing by the number of ice covered days. Exogenous inputs of nitrate from stream water and groundwater to these lakes accounted for only 0 to $13 \%$ of the nitrate accumulation. Thus, in-lake nitrification, which consumes oxygen, was likely responsible for generating the majority of the nitrate. However, the influence of nitrification on winter oxygen dynamics has not yet been quantified in these lakes, and has rarely been addressed in lakes overall (but see Knowles and Lean 1987; Liao and Lean 1978).

Here, we examine the stoichiometric oxygen requirements of nitrification, and potential influences of nitrification on winter dissolved oxygen (DO) dynamics, through comparison of winter DO depletion and $\mathrm{NO}_{3}-\mathrm{N}$ accumulation rates. This research builds on findings of winter nitrate accumulation in Powers et al. (2017), again using the number of days since iceon to account for seasonal forcing, with the addition of new oxygen data. We also include new data sets for two bog lakes that routinely experience winter DO concentrations below $1.0 \mathrm{mg} \mathrm{L}^{-1}$, enabling comparisons between lakes that vary in trophic status. In total, more than 30 years of winter data for nitrate, DO, and supporting physico-chemical dynamics were explored in seven seasonally frozen north temperate lakes.

\section{Methods}

We used 30 + years of winter limnological data from seven study lakes of the North Temperate Lakes Long- 
Term Ecological Research (NTL-LTER) project (Allequash, Big Muskellunge (hereon Big Musky), Crystal, Sparkling, and Trout Lakes, as well as Crystal and Trout Bogs; https://lter.limnology.wisc.edu), located in northern WI, USA. Maximum lake depth ranged from 2.5 to $35 \mathrm{~m}$. Lake depth, ice duration, winter data availability, and mean winter conditions are summarized in Table 1. Each lake was sampled 2-3 times each winter and water chemistry was determined using consistent field and laboratory methodologies. Under-ice water samples were taken over the deepest point of each lake at three depths through a $20 \mathrm{~cm}$ bore hole: surface $(0-5 \mathrm{~cm}$ below the bottom of the ice), deep ( $1 \mathrm{~m}$ above lake bottom), and midpoint of the water column for water chemistry. Temperature and DO profiles were measured at 1-m intervals. Our analysis focuses on nitrate + nitritenitrogen (hereafter $\mathrm{NO}_{3}-\mathrm{N}, \mu \mathrm{g} \mathrm{L}^{-1}$ ), and $\mathrm{DO}$ $\left(\mathrm{mg} \mathrm{L}^{-1}\right)$, with supporting physico-chemistry for ammonium $\left(\mathrm{NH}_{4}-\mathrm{N}, \mathrm{mg} \mathrm{L}^{-1}\right)$ and dissolved inorganic carbon (DIC, $\mathrm{mg} \mathrm{L}^{-1}$ ). For each sampling date, we also calculated depth-integrated, whole water column DO concentration using vertical profiles. Expanded methods are in the SI.

Relationships between concentration and days since ice-on

With days since ice-on as our time variable, we used linear mixed effects models (Bates et al. 2015) to estimate lake-specific and depth-specific rates of change in $\mathrm{NO}_{3}-\mathrm{N}$ and $\mathrm{DO}$ over winter (random intercepts for each lake, depth, and variable; SI). In model fitting for DO declines and $\mathrm{NO}_{3}-\mathrm{N}$ accumulation, we focused on the linear portion over the first 100 days since ice-on, prior to ice thinning, which included the majority of data. To avoid interpolation across a sampling gap during early winter, which applied to bog lakes only, we used a fitting window that excluded the first 7 days after ice-on. All available winter data were used to guide interpretations. Analyses and figures were produced using $\mathrm{R}$ ( $\mathrm{R}$ Core Team 2016). Loess fits were used for visualization.

\section{Potential oxygen consumption by nitrifiers}

We calculated the potential DO consumption required to produce the fitted winter $\mathrm{NO}_{3}-\mathrm{N}$ accumulation rates via nitrification. This estimation was made using the
$\mathrm{N}: \mathrm{O}$ stoichiometry for autotrophic nitrification reactions. The overall reaction of nitrification is:

$\mathrm{NH}_{4}^{+}+2 \mathrm{O}_{2} \rightarrow \mathrm{NO}_{3}^{-}+2 \mathrm{H}^{+}+\mathrm{H}_{2} \mathrm{O}$

and requires consumption of $2 \mathrm{~mol}_{2}$ per mole of $\mathrm{NO}_{3}-\mathrm{N}$ produced. In the underlying steps, ammonium is oxidized first to nitrite $\left(\mathrm{NO}_{2}^{-}\right)$, then to $\mathrm{NO}_{3}^{-}$, by microbes. Using the 2:1 molar ratio, molar $\mathrm{NO}_{3}-\mathrm{N}$ accumulation rates were converted into units of potential DO consumption, then compared to the observed DO depletion in open water. These calculations were first performed depth-specifically, by comparing the potential DO consumption rates by nitrifiers to DO depletion rates from the same depth.

Ecosystem-level quantification of $\mathrm{NO}_{3}-\mathrm{N}$

accumulation and DO depletion rates

To produce estimates of the ecosystem-level nitrate accumulation and oxygen depletion rates, we require assumptions about the height of water represented by each sampling depth. These representative water heights are not known, reflecting complications from highly dynamic and depth-penetrating mixing patterns that have been revealed in recent winter research (Pernica et al. 2017; Bruesewitz et al. 2014). Because nitrification is thought to be a benthic-dominated process in these lakes (Powers et al. 2017), estimates of ecosystem-level oxygen consumption by nitrification may be obtained through knowledge of the sediment surface area associated with a given depth. In Big Musky, Crystal, Sparkling, Trout, $>70 \%$ of the benthic surface area occurs closer to the middle sampling depth than the deep or surface sampling depths (SI), while Allequash had $49 \%$ of benthic surface area closer to middle depth.

To address the above complexities, we considered five alternative approaches to ecosystem-level flux estimation using chemical data combined with hypsometry data at $0.5 \mathrm{~m}$ intervals, which explains the proportion of surface area represented by a given depth interval. Similar approaches have been employed relatively recently to calculate whole-system fluxes (Beaulieu et al. 2014; Deemer et al. 2011; Grantz et al. 2012). Each approach incorporates different assumptions about the weighting of surface, middle, and deep samples in ecosystem-level quantification. The five approaches are described below. 


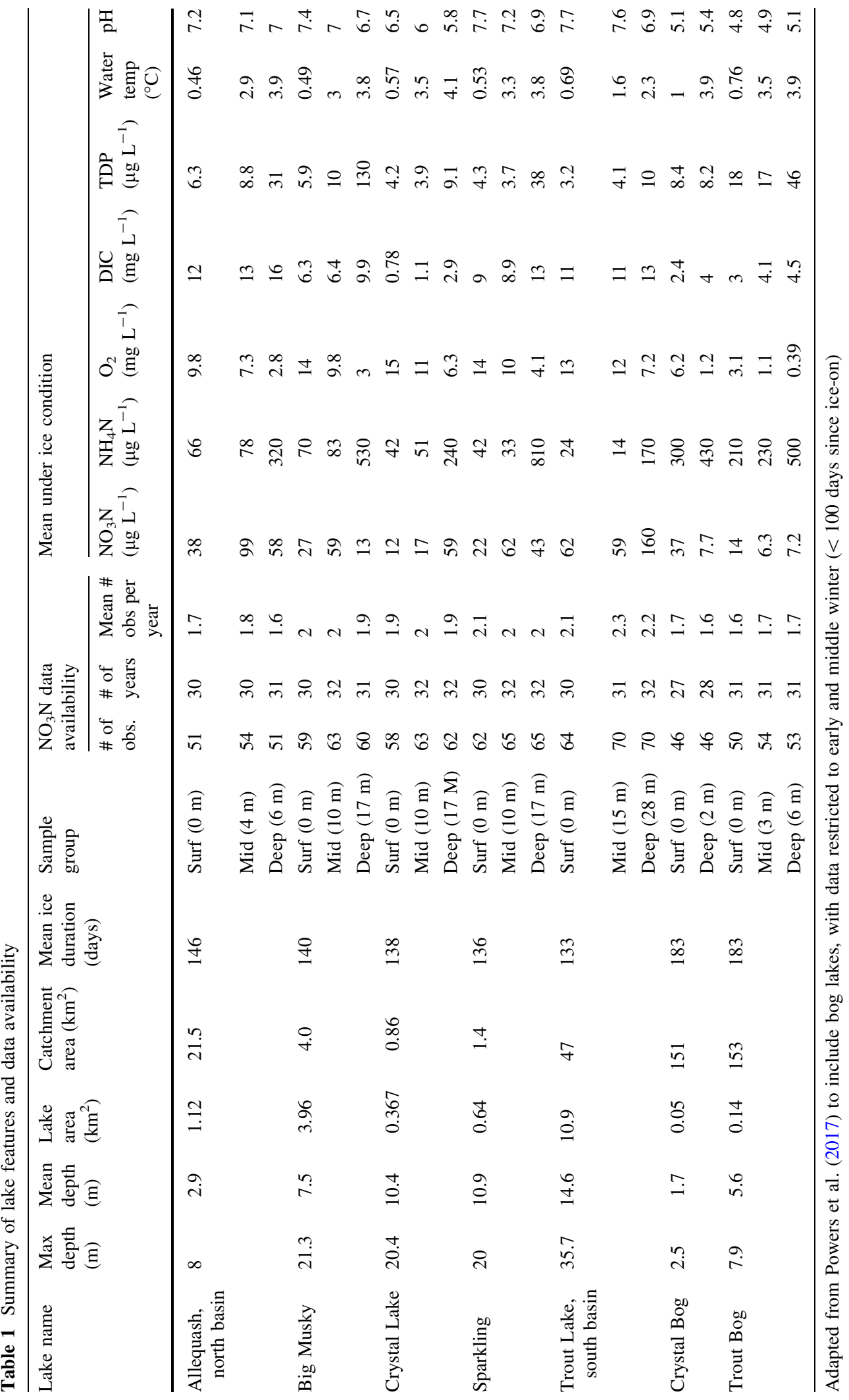


(1) Depth-ignorant fit: No depth weights used. For each solute, a single coefficient describing the rate of change was fit across depths. (2) Simple hypsometrically-weighted approach: Surface height $=0.5 \times$ middle depth, excluding surface-middle boundary depth; deep height $=$ lake $\max$ depth $-0.5 \times($ deep depth + middle depth), excluding middle-deep boundary depth; rest of water height goes to middle; water heights converted to hypsometric weights using hypsometry data. (3) Hypsometrically-weighted with a conservative surface zone: Surface height $=0.5 \mathrm{~m}$; deep height $=$ lake max depth $-0.5 \times($ deep depth + middle depth), excluding middle-deep boundary depth; rest of water height goes to middle; water heights converted to hypsometric weights using hypsometry data. (4) Hypsometrically-weighted with a conservative surface zone and a conservative deep zone: Surface height $=0.5 \mathrm{~m}$; deep water height bounded by the lake bottom and $1 \mathrm{~m}$ above the deep sampling depth; rest of water height goes to middle; water heights converted to hypsometric weights using hypsometry data. (5) Simple middle depth rate as an indicator of the ecosystem-level rate: This approach does not require further assumptions about the height of water that each sample represents; depth weights are surface $=0$, middle $=1$, deep $=0$.

The degree of "middle-weightedness" for these approaches is as follows: 5 (most middle-weighted), 4 , 3, 2, 1 (least middle-weighted). In the reported results, we emphasize the minimum and maximum estimates obtained from these five approaches.

\section{Results}

Oxygen declined over winter at middle and deep sampling depths in all seven lakes (Fig. 1). Among the five oligotrophic-mesotrophic lakes, fitted DO depletion rates were highest in deep water, ranging from $50 \mu \mathrm{g} \mathrm{L}^{-1}$ days $^{-1}$ (5.0 $\mathrm{mg} \mathrm{L}^{-1}$ per 100 days) in Big Musky Lake to $71 \mu \mathrm{g} \mathrm{L}^{-1}$ days $^{-1}$ in Allequash Lake (1.55-2.23 $\mu \mathrm{M}$ days $^{-1}$, Table S1), and lowest at the surface, ranging from $7.2 \mu \mathrm{g} \mathrm{L}^{-1}$ days $^{-1}$ in Allequash to $21 \mu \mathrm{g} \mathrm{L}^{-1}$ days $^{-1}$ in Big Musky $(0.23-0.66 \mu \mathrm{M}$ days $^{-1}$ ). Hypoxia developed in some years in the deep layer of Allequash and Big Musky, after about 50 days since ice-on. Deep waters of Trout remained relatively oxygenated (DO $\left.>2.5 \mathrm{mg} \mathrm{L}^{-1}\right)$ and colder (mean $<3{ }^{\circ} \mathrm{C}$ ) than the other lakes. The two bog lakes (Trout Bog and Crystal Bog) typically became nearly anoxic $\left(<0.5 \mathrm{mg} \mathrm{L}^{-1} \mathrm{DO}\right)$ or hypoxic $\left(<3 \mathrm{mg} \mathrm{L}^{-1}\right.$ DO) over the majority of the water column by 60 days since ice-on, although surface water typically remained oxygenated $\left(3-10 \mathrm{mg} \mathrm{L}^{-1}\right.$ ) during winter.

All lakes began the ice-on period with similar and relatively low $\mathrm{NO}_{3}-\mathrm{N}$ concentrations across all depths. In all lakes, deep water was more DOdepleted, DIC-rich, and $\mathrm{NH}_{4}-\mathrm{N}$-rich relative to middle and surface depths. In oligotrophic-mesotrophic lakes, there was a progressive shift from $\mathrm{NH}_{4}-\mathrm{N}$ dominance to $\mathrm{NO}_{3}-\mathrm{N}$ dominance of the DIN pool over the course of winter, with $\mathrm{NO}_{3}-\mathrm{N}$ concentrations $>100 \mu \mathrm{g} \mathrm{L}^{-1}$ at middle depth by late winter $(\sim 100$ days since iceon) (Fig. 2). In Allequash, Big Musky, and Sparkling Lakes, model-fitted $\mathrm{NO}_{3}-\mathrm{N}$ accumulation rates between 0 and 100 days since ice-on were highest at middle depth (Fig. 3). Trout Lake and Crystal Lake had higher $\mathrm{NO}_{3}-\mathrm{N}$ accumulation rates in deep water (Trout $=3.0 \mu \mathrm{g} \mathrm{L}^{-1}$ days $^{-1}$; Crystal $=1.1 \mu \mathrm{g} \mathrm{L}^{-1}$ days $^{-1}$ ) than at middle or surface depths. Trout Lake was unique in having a pronounced decline in deep water $\mathrm{NO}_{3}-\mathrm{N}$ after 100 days since ice-on. In the two bog lakes, $\mathrm{NO}_{3}-\mathrm{N}$ accumulation was restricted to late winter, near the ice surface.

Based on the co-occurring rates of $\mathrm{NO}_{3}-\mathrm{N}$ accumulation and DO depletion at a given depth, potential oxygen use by nitrifiers ranged from 1 to $25 \%$ of the DO depletion rate (Fig. 4). Among oligotrophicmesotrophic lakes that had non-negligible DO declines $(\mathrm{n}=14$, excludes surface of Allequash Lake), the mean potential oxygen use by nitrifiers was $9 \%$. In deep water, potential oxygen use by nitrifiers represented 5-19\% of DO depletion in Allequash, Crystal, Sparkling, and Trout (Fig. 4), but $<1 \%$ in Big Musky. At surface and middle depths of Sparkling and Trout, nitrifier oxygen demand represented $10-18 \%$ of the fitted oxygen depletion rate, as did the middle depth of Allequash and Big Musky.

Across the five different approaches to ecosystemlevel quantification (Table S2), nitrifier oxygen demand in Allequash Lake represented $8-10 \%$ of the DO depletion, and corresponding estimates were 7-14\% in Sparkling, 5-13\% in Big Musky, 9-15\% in Trout, $4-7 \%$ in Crystal, $2-3 \%$ in Trout Bog, and $<2 \%$ in shallower Crystal Bog based on the two available sampling depths (surface and $2 \mathrm{~m}$ ). In both bog lakes, much DO depletion occurred during unsampled periods of early winter, and the nitrogen dynamics during this time are not yet known. 
Fig. 1 Winter oxygen depletion expressed using the number of days since ice-on. Data are from deep, middle, and surface of the lake. Integrated water column concentrations from complete oxygen profiles (1$m$ intervals) are also shown. Lines are loess fits to aid visualization of winter trends. Lakes are generally not sampled during the first few weeks of ice-on, except the two bog lakes during years with early ice arrival

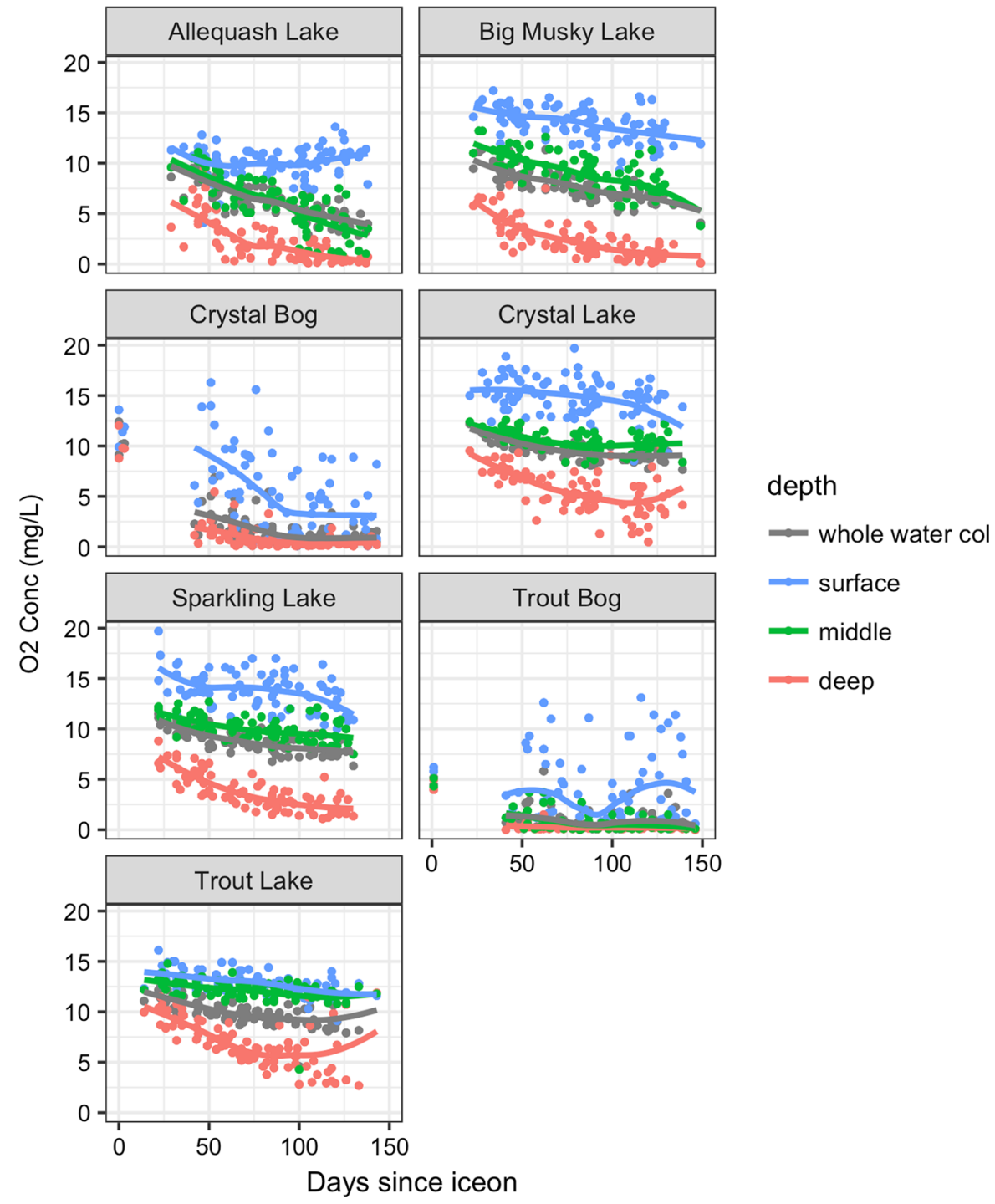

\section{Discussion}

Winter is a critical period of anoxia risk in lakes, and nitrification can hasten the transition between aerobic and anaerobic conditions (Clevinger et al. 2014; Hall and Jeffries 1984), with broad ecological and biogeochemical consequences (Gu 2012). Our results indicate that nitrification occurs in seasonally-frozen forested lakes at temperatures $<5{ }^{\circ} \mathrm{C}$, at ecosystem-relevant rates that influence not only water column $\mathrm{N}$ speciation, but also oxygen supply. A study of winter conditions in more eutrophic lakes by Knowles and Lean (1987) provides one of the few other examples in which oxygen loss via nitrification has been examined beneath seasonal ice cover. Such observations during seasonal ice cover provide a unique window on oxygen and nitrogen cycles of lakes, when exogenous inputs from the atmosphere, precipitation, and the surrounding landscape are minimal. Because an unknown amount of $\mathrm{NO}_{3}-\mathrm{N}$ was consumed by algal uptake and denitrification, these apparent $\mathrm{NO}_{3}-\mathrm{N}$ accumulation rates represent net nitrification and are likely conservative estimates for gross nitrification and gross oxygen consumption by nitrifiers. Our results raise the possibility that oxygen-based studies and models of aerobic respiration and primary production under ice 

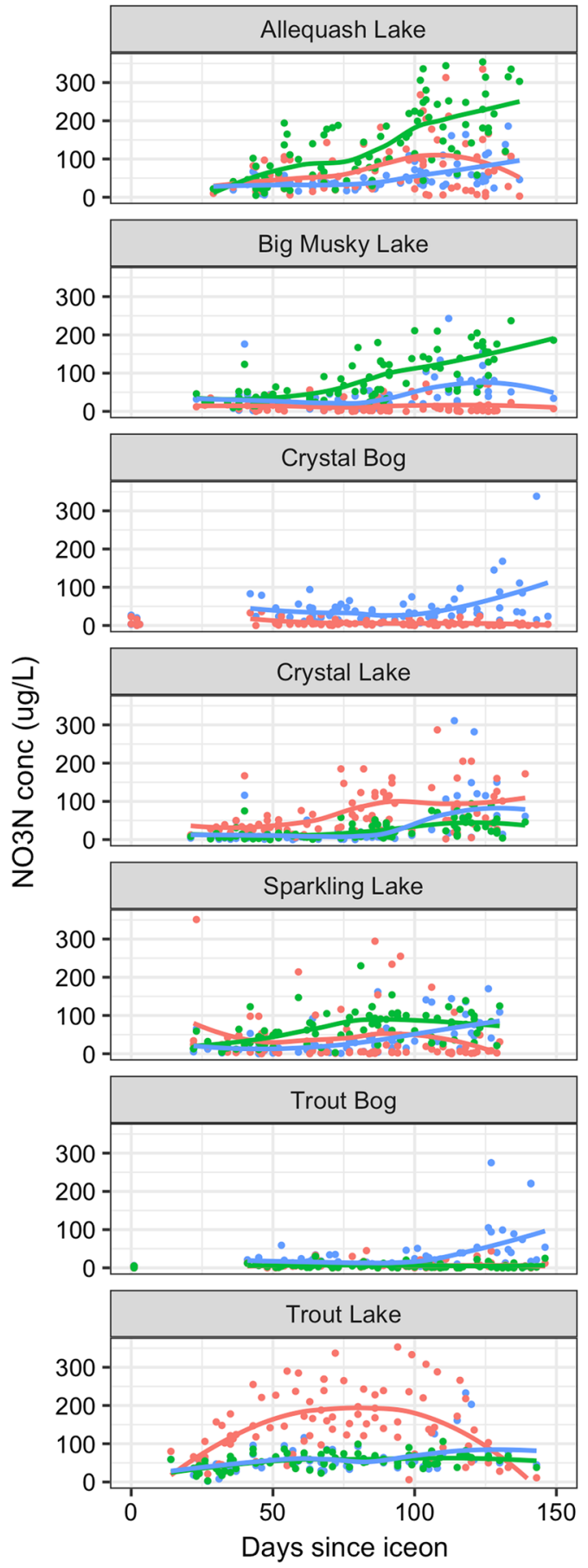

Fig. 2 Nitrate $\left(\mathrm{NO}_{3}-\mathrm{N}\right)$ observations in deep, middle, and surface water expressed as a function of the number of days since ice-on. Adapted from Powers et al. (2017). In the right

may be advanced by incorporating nitrifier effects. The lack of air-water gas exchange during ice cover offers useful opportunities to test the biological components
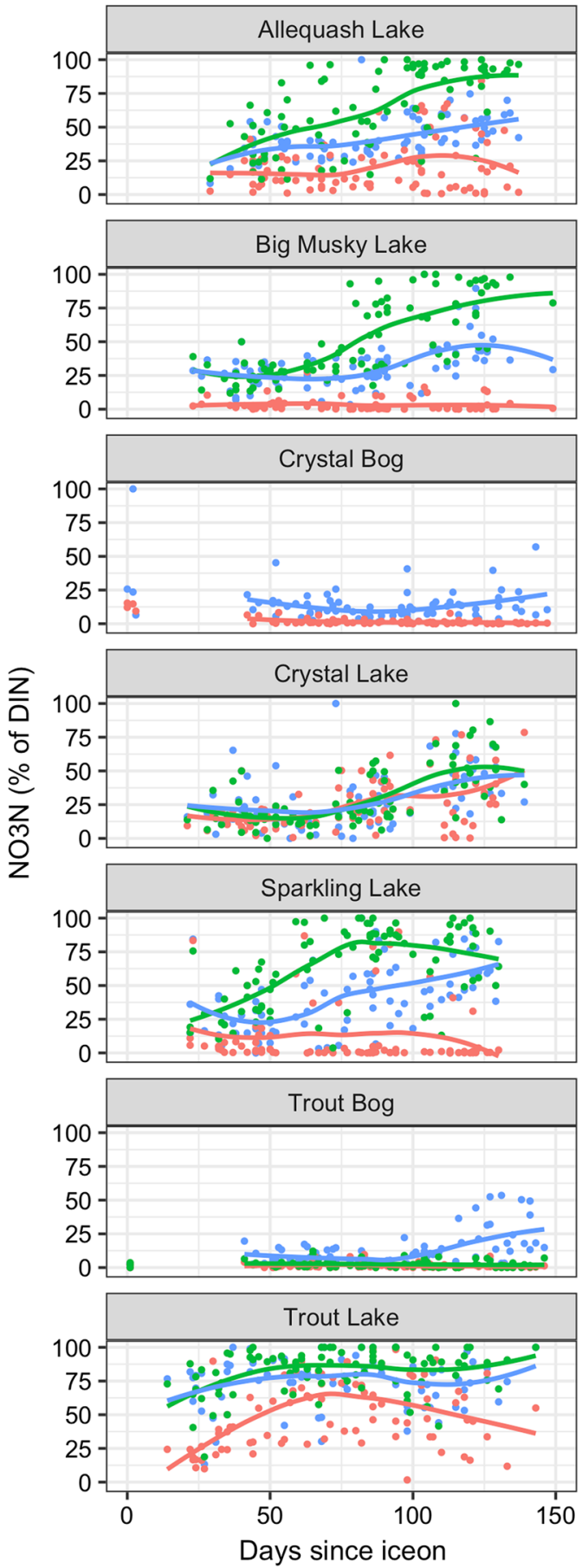

column, nitrate is plotted as the \% of DIN $\left(\mathrm{NO}_{3}-\mathrm{N}+\mathrm{NH}_{4}-\mathrm{N}\right)$. Lines are loess fits to aid visualization of winter trends. A few high values exceed the plotted scale

of oxygen-based ecosystem metabolism models, inclusive to nitrification and aerobic or anaerobic processes (Hanson et al. 2006). 


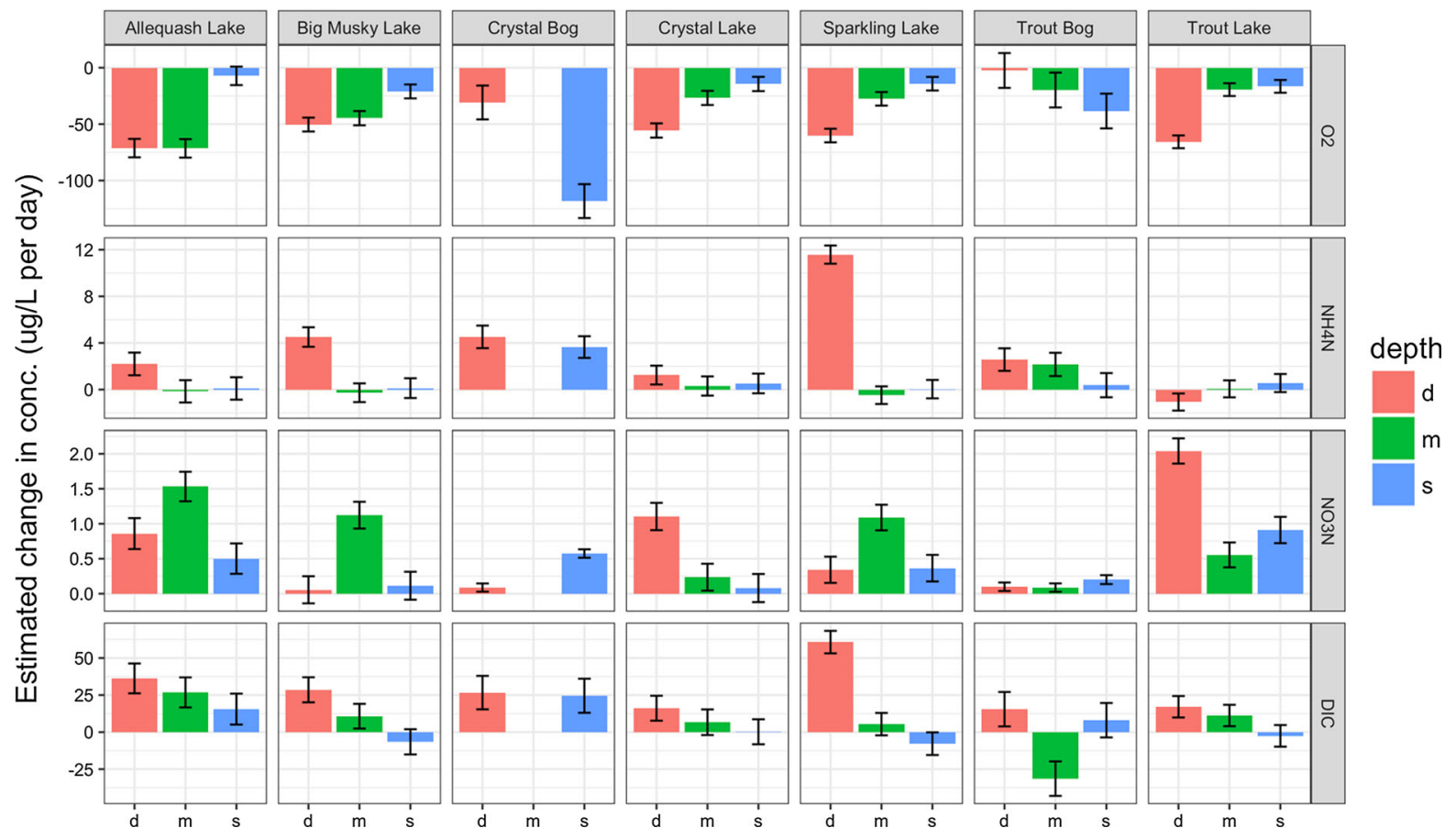

Fig. 3 Fitted winter changes in dissolved $\mathrm{O}_{2}, \mathrm{NH}_{4}-\mathrm{N}, \mathrm{NO}_{3}-\mathrm{N}$, and DIC under ice in the seven lakes over the first 100 days since ice-on. Estimates are from linear mixed effects models. Whole

In oligotrophic-mesotrophic lakes during early and middle winter ( 0 to 100 days since ice-on), the oxygen requirement to support observed nitrate accumulation (Fig. 4) ranged from 1 to $25 \%$ of the DO depletion rates at those depths (mean of 9\%). These calculations were based on observations showing that nitrate often accumulated over winter, especially in shallower oligotrophic-mesotrophic lakes (Allequash and Big Musky), and near the bottom of two deeper oligotrophic lakes (Crystal Lake and Trout Lake). Simultaneously there were pronounced winter DO declines across multiple lakes and depths, especially for middle and deep samples. Given the potential for interannual variability, these negative relationships between DO and days since iceon were relatively strong. The observed patterns of oxygen depletion reflect aerobic respiration of organic carbon combined with autotrophic, oxygen-consumptive processes such as nitrification and methane oxidation. Autotrophic oxygen consumption has not been frequently addressed in oxygen-based ecosystem metabolism models but could apply to other lakes during ice cover. A remaining question is: Why do nitrifier contributions to oxygen depletion vary among lakes? Possibilities (gray) indicates fitted values are from data at all 3 depths. Note different $\mathrm{y}$-axis for each row. Key: $\mathrm{d}=$ deep, $\mathrm{m}=$ middle, $\mathrm{s}=$ surface

are that nitrification is lower in lakes with low surface:volume ratios such as Trout Lake, or lakes with high water clarity such as Crystal Lake, where ammonium oxidizers can be inhibited by light.

Nitrate accumulation and DO declines were more pronounced in middle and deep water compared to the surface, likely because nitrification and respiration occur predominantly in the benthos, as has been widely reported in other aquatic environments (e.g., Pauer and Auer 2000). Photosynthesis and algal uptake of nitrate in surface waters could be masking the nitrification signal. However, surface water samples represented a relatively thin layer of the water column according to temp-DO profiles (Powers et al. 2017). Denitrification may also co-occur in deep water through coupled nitrification-denitrification, although the observed $\mathrm{NO}_{3}-\mathrm{N}$ accumulation implies that nitrification exceeds denitrification under ice in these forested lakes. Net nitrification can occur if nitrification and denitrification are decoupled, as might be expected when $\mathrm{N}$ mineralization occurs in an aerobic matrix. Functional dominance by intermediate depths is further supported by the correspondence between middle and depth-integrated DO dynamics in Fig. 1. 
Fig. 4 Potential oxygen demand required to produce the fitted whole winter nitrate accumulation rate via nitrification. Whole (gray) indicates fitted values are from data at all 3 depths. White space indicates no significant nitrate accumulation. "L" indicates Lake. Note that for Allequash surface and Trout Bog deep, the fitted rate of oxygen depletion was insignificant over the sampled period (standard error $>$ coefficient)
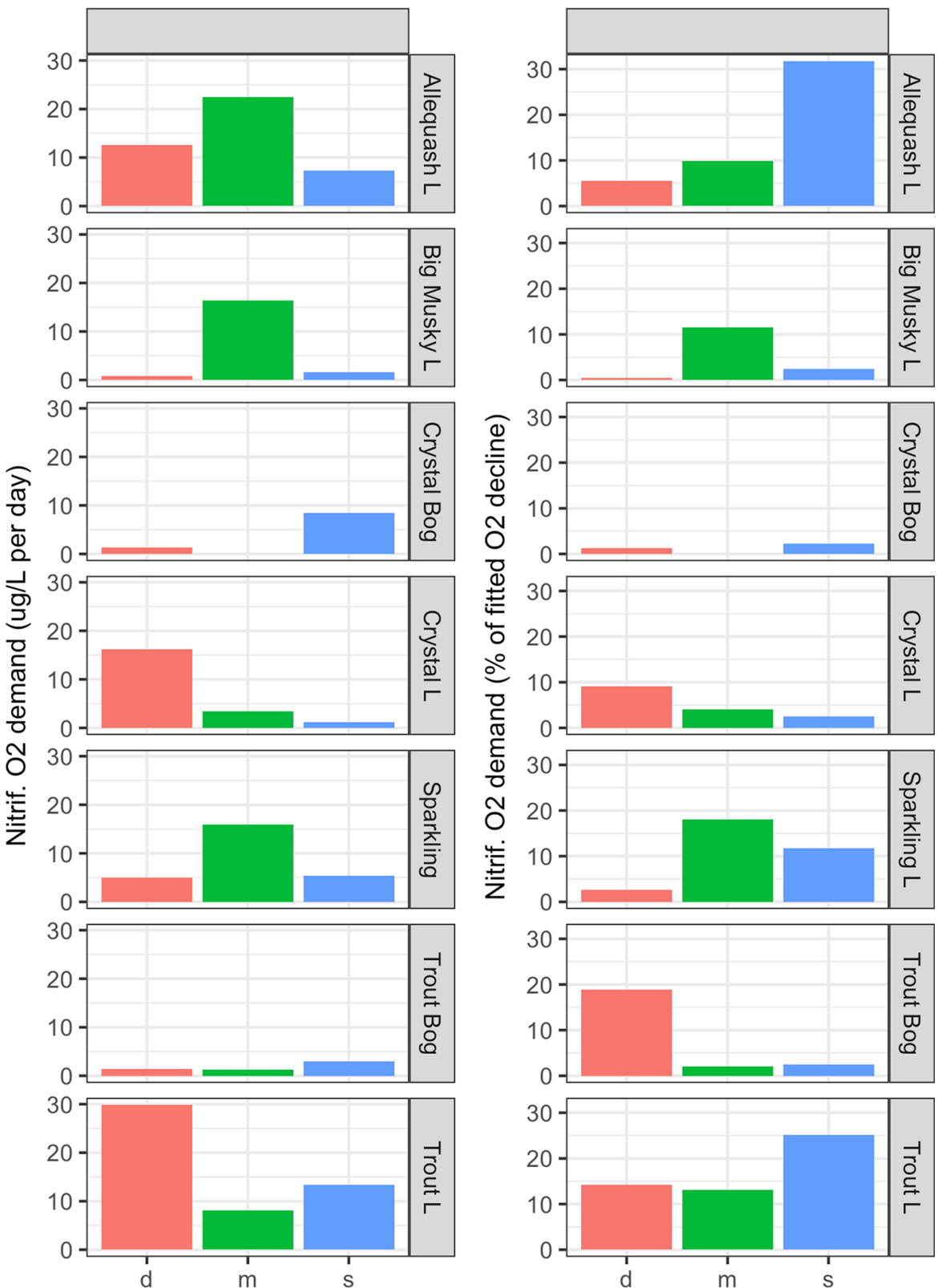

The variation in water chemistry between depths implies at least some degree of stratification, and thus the presence of $\mathrm{NO}_{3}-\mathrm{N}$ may reflect depth-specific nitrification. However, in three lakes, surface and middle $\mathrm{NO}_{3}-\mathrm{N}$ coincided with $\mathrm{NH}_{4}-\mathrm{N}$ accumulation in deep waters (Allequash, Big Musky, Sparkling, Powers et al. 2017), suggesting some vertical transfer of $\mathrm{N}$ and/or DO, especially during late winter. Below $4.0^{\circ} \mathrm{C}$, water density increases as it warms (Wetzel 2001), and relatively small density gradients under ice may promote circulation (Bruesewitz et al. 2014), perhaps delivering oxygenated water to benthic nitrifiers; this provides a possible explanation for the maintenance of DO concentrations above $2.5 \mathrm{mg} \mathrm{L}^{-1}$ in deep water of Crystal and Trout, the two deepest lakes $(>20 \mathrm{~m})$, which in turn had the highest deepwater $\mathrm{NO}_{3}-\mathrm{N}$ accumulation rates.

Compared to the oligotrophic-mesotrophic lakes, winter oxygen depletion in two smaller bog lakes (Crystal Bog and Trout Bog) proceeded more rapidly. 
The lack of $\mathrm{NO}_{3}-\mathrm{N}$ accumulation during early and midwinter in these bog lakes may reflect an absence of nitrification, or coupled nitrification-denitrification. However, $\mathrm{NO}_{3}-\mathrm{N}$ did sometimes accumulate in bog lakes during late winter, suggesting nitrification may be supported by biogenic oxygen during enhanced photosynthesis under thinning ice or clear ice (Katz et al. 2015; Kerfoot et al. 2008), which has not been commonly demonstrated in bog lakes. In the oligotrophic-mesotrophic lakes, oxic conditions were typically maintained throughout winter. The lack of pronounced winter oxygen declines in surface samples of Allequash Lake, Crystal Lake, and Trout Bog could be explained by a combination of winter photosynthesis and low aerobic respiration. A more integrated understanding of winter oxygen dynamics across diverse lakes combined with ice phenology trends (Jensen et al. 2007; Magnuson et al. 2000) may increase understanding about the biogeochemical consequences of a changing winter.

Acknowledgements Funding was provided by the National Science Foundation (NSF DEB \#1431428; NSF DEB \#1136637), North Temperate Lakes Long-term Ecological Research (NTL-LTER) project (NSF DEB-1440297), and Washington State University. We thank the dedicated scientists who have sustained field sampling and laboratory efforts of the NTL-LTER project. In particular we thank Pam Montz and Tim Meinke who have collected the vast majority of samples used in this study. Several people provided generous input on this research following the "Ecology under ice" session at the 2016 ASLO meeting in Santa Fe, New Mexico.

Open Access This article is distributed under the terms of the Creative Commons Attribution 4.0 International License (http:// creativecommons.org/licenses/by/4.0/), which permits unrestricted use, distribution, and reproduction in any medium, provided you give appropriate credit to the original author(s) and the source, provide a link to the Creative Commons license, and indicate if changes were made.

Author contributions SMP led the manuscript effort. SMP and EHS generated the research questions and designed the study approach. SMP, SEH, and SGL contributed to statistical analyses. SMP and SGL contributed figures. EHS and NRL contributed data. SMP, EHS, HMB, NRL, and SEH interpreted results. All authors contributed to writing of the paper.

\section{References}

Bates D, Mächler M, Bolker B, Walker S (2015) Fitting linear mixed-effects models using lme4. J Stat Soft 67:1-48
Beaulieu JJ, Smolenski RL, Nietch CT et al (2014) Denitrification alternates between a source and sink of nitrous oxide in the hypolimnion of a thermally stratified reservoir. Limnol Oceanogr 59:495-506. doi:10.4319/lo.2014.59.2. 0495

Bertilsson S, Burgin A, Carey C, Fey S, Grossart H, Grubisic L, Jones I, Kirillin G, Lennon J, Shade A, Smyth R (2013) The under-ice microbiome of seasonally frozen lakes. Limnol Oceanogr 58:1998-2012. doi:10.4319/lo.2013.58.6.1998

Bruesewitz DA, Carey CC, Richardson DC, Weathers KC (2014) Under-ice thermal stratification dynamics of a large, deep lake revealed by high-frequency data. Limnol Oceanogr 60:347-359

Clevinger CC, Heath RT, Bade DT (2014) Oxygen use by nitrification in the hypolimnion and sediments of Lake Erie. J Great Lakes Res 40:202-207. doi:10.1016/j.jglr. 2013.09.015

Deemer BR, Harrison JA, Whitling EW (2011) Microbial dinitrogen and nitrous oxide production in a small eutrophic reservoir: an in situ approach to quantifying hypolimnetic process rates. Limnol Oceanogr 56:1189-1199. doi:10.4319/lo.2011.56.4.1189

Denfeld BA, Kortelainen P, Rantakari M, Sobek S, Weyhenmeyer GA (2016) Regional variability and drivers of below ice $\mathrm{CO}_{2}$ in boreal and subarctic lakes. Ecosystems 19:461-476. doi:10.1007/s10021-015-9944-z

Ducharme-Riel V, Vachon D, del Giorgio PA, Prairie YT (2015) The relative contribution of winter under-ice and summer hypolimnetic $\mathrm{CO}_{2}$ accumulation to the annual $\mathrm{CO}_{2}$ emissions from Northern Lakes. Ecosystems 18:547-559. doi:10.1007/s10021-015-9846-0

French E, Kozlowski JA, Mukherjee M, Bullerjahn G, Bollmann M (2012) Ecophysiological characterization of ammoniaoxidizing Archaea and Bacteria from freshwater. Appl Environ Microbiol 78:5773-5780. doi:10.1128/AEM. 00432-12

Gammons CH, Henne W, Poulson SR, Parker SR, Johnston TB, Dore JE, Boyd ES (2014) Stable isotopes track biogeochemical processes under seasonal ice cover in a shallow, productive lake. Biogeochemistry 120:359-379. doi:10. 1007/s10533-014-0005-z

Grantz EM, Kogo A, Scott JT (2012) Partitioning whole-lake denitrification using in situ dinitrogen gas accumulation and intact sediment core experiments. Limnol Oceanogr 57:925-935. doi:10.4319/lo.2012.57.4.0925

Gu B (2012) Stable isotopes as indicators for seasonally dominant nitrogen cycling processes in a subarctic lake. Int Rev Hydrobiol 97:233-243. doi:10.1002/iroh.201111466

Hall GH, Jeffries C (1984) The contribution of nitrification in the water column and profundal sediments to the total oxygen deficit of the hypolimnion of a mesotrophic lake. Microb Ecol 10:37-46. doi:10.1007/BF02011593

Hampton SE, Galloway AWE, Powers SM, Ozersky T, Woo KH, Batt RD, Labou SG, O'Reilly CM, Sharma S, Lottig NR, Stanley EH et al (2017) Ecology under lake ice. Ecol Lett 20:98-111

Hanson PC, Carpenter SR, Armstrong Stanley EH, Kratz TK (2006) Lake dissolved organic carbon and dissolved oxygen: changing drivers from days to decades. Ecol Monogr 76:343-363. doi:10.1890/0012-9615(2006)076[0343:LDICAD]2.0.CO;2 
Jensen OP, Benson BJ, Magnuson JJ, Card VM, Futter MN, Soranno PA, Stewart KM (2007) Spatial analysis of ice phenology trends across the Laurentian Great Lakes region during a recent warm period. Limnol Oceanogr 52:2013-2026. doi:10.4319/lo.2007.52.5.2013

Katz SL, Izmest'eva LR, Hampton SE, Ozersky T, Shchapov K, Moore MV et al (2015) The "Melosira years" of Lake Baikal: winter environmental conditions at ice onset predict under-ice algal blooms in spring. Limnol Oceanogr 60:1950-1964. doi:10.1002/lno.10143

Kerfoot WC, Budd JW, Green SA, Cotner JB, Biddanda BA, Schwab DJ, Vanderploeg HA (2008) Doughnut in the desert: late-winter production pulse in southern Lake Michigan. Limnol Oceanogr 53:589-604. doi:10.4319/lo. 2008.53.2.0589

Kirillin G, Leppäranta M, Terhevik A, Granin N, Bernhardt J, Engelhardt C, Efremova T, Golosov S, Palshin N, Sherstyankin P, Zdorovennova G, Zdorovennov R (2012) Physics of seasonally ice-covered lakes: a review. Aquat Sci 74:659-682. doi:10.1007/s00027-012-0279-y

Knowles R, Lean DRS (1987) Nitrification: a significant cause of oxygen depletion under winter ice. Can J Fish Aquat Sci 44:743-749

Liao CF, Lean DRS (1978) Seasonal changes in nitrogen compartments of lakes under different loading conditions. J Fish Res Board Can 35:1095-1101

Magnuson JJ, Beckel AL, Mills K, Brandt SB (1985) Surviving winter hypoxia: behavioral adaptations of fishes in a northern Wisconsin winterkill lake. Environ Biol Fishes 14:241-250. doi:10.1007/BF00002627

Magnuson JJ, Robertson DM, Benson BJ, Wynne RH, Livingstone DM, Arai T, Assel RA, Barry RG, Card V, Kuusisto E, Granin NG, Prowse TD, Stewart KM, Vuglinski VS (2000) Historical trends in lake and river ice cover in the Northern Hemisphere. Science 289:1743-1746. doi:10. 1126/science.289.5485.1743

McKnight DM, Howes BL, Taylor CD, Goehringer DD (2000) Phytoplankton dynamics in a stably stratified Antarctic lake during winter darkness. J Phycol 36:852-861. doi:10. 1046/j.1529-8817.2000.00031.x
Morgan-Kiss RM, Lizotte MP, Kong W, Priscu JC (2016) Photoadaptation to the polar night by phytoplankton in a permanently ice-covered Antarctic lake. Limnol Oceanogr 61:3-13

Pauer JJ, Auer MT (2000) Nitrification in the water column and sediment of a hypereutrophic lake and adjoining river system. Water Res 34:1247-1254. doi:10.1016/S00431354(99)00258-4

Pernica P, North RL, Baulch HM (2017) In the cold light of day: The potential importance of under ice convective mixed layers to primary producers. Inland Waters 7:138-150. doi:10.1080/20442041.2017.1296627

Powers SM, Hampton SE (2016) Winter limnology as a new frontier. Limnol Oceanogr Bull 25:103-108

Powers SM, Labou SG, Baulch HM, Hunt RJ, Lottig NR, Hampton SE, Stanley EH (2017) Ice duration drives winter nitrate accumulation in north temperate lakes. Limnol Oceanogr. doi:10.1002/lol2.10048

R Core Team (2016) R: a language and environment for statistical computing. R Foundation for Statistical Computing, Vienna, Austria. https://www.R-project.org/. Accessed 31 Oct 2016

Striegl RG, Kortelainen P, Chanton J, Wickland KP, Bugna GC, Rantakari M (2001) Carbon dioxide partial pressure and $13 \mathrm{C}$ content of north temperate and boreal lakes at spring ice melt. Limnol Oceanogr 46:941-945. doi:10.4319/lo. 2001.46.4.0941

Verpoorter C, Kutser T, Seekell DA, Tranvik LJ (2014) A global inventory of lakes based on high-resolution satellite imagery. Geophys Res Lett 41:6396-6401. doi:10.1002/ 2014GL060641

Wetzel RG (2001) Limnology: lake and river ecosystems, 3rd edn. Gulf Professional Publishing, Houston

Winslow LA, Zwart JA, Batt RD, Dugan HA, Woolway RI, Corman JR, Hanson PC, Read JS (2016) LakeMetabolizer: an $\mathrm{R}$ package for estimating lake metabolism from freewater oxygen using diverse statistical models. Inland Waters 6:622-636 